\title{
Education and Religious Intolerance in Nigeria: The Need for Essencism as a Philosophy
}

\author{
Barrister Samuel Asuquo Ekanem, Ph.D
}

\author{
Department of Educational Foundations And Administration \\ Faculty of Education, Cross River University of Technology, Calabar - Nigeria.
}

Ekeng Nyong Ekefre, Ph.D

Department of Educational Foundations And Aministration Faculty Of Education, Cross River University of Technology, Calabar- nigeria

\author{
Doi:10.5901/jesr.2013.v3n2p303
}

\begin{abstract}
Nigeria as a nation is plaque with several socio-political and economic problems and challenges. However, the major challenges facing the country since 2007 that tend to defy all logic and solution is that of insecurity posed by the Boko Haram insurgency. Boko Haram, which literarily means "Western Education is sin", according to the local parlance, is deeply rooted in religious intolerance. Historically, religious intolerance dates back to the 1980s when the Maitasine sect emerged. This sect posed a serious threat to the unity of the country. Due to the massive killing by the Maitasine sect, the country became polarized along religious line. The government managed to contend the sect somehow, but the "mustard seed" of that religious crisis was deeply planted and watered, so, the seed has been germinating with diverse botanical names. A deep reflection on religious intolerance in Nigeria will reveal that the problem is deeply rooted in the north. And this is the part of the country where the illiteracy rate is the highest. Again,the north, which is predominantly Moslem see everything with the spectacle of religion. The north as a people does not have a culture that is different from religion. Indeed, everything to an average northerner who is a Moslem is viewed from Islamic religion. So, to them, there are no differences between culture, politics and religion. This knitted relationship between these basic social elements in the north makes it difficult to establish a distinction between the three. So, a disagreement in any aspect of these social elements is viewed as a disagreement of religious view or belief. This usually and perennially creates tension in the country especially in the north. To solve this problem therefore, there is the need for education to illuminate and liberate the minds of the masses in the north. This will like the Platonic "allegory of the cave" salvage and unchain the people from darkness and pole of illiteracy. Through education nourished with philosophy of Essencism, the paper contends that. Nigerians will be able to overcome the challenge of religious intolerance and sustain the basic principles of secularity, freedom of worship, and other fundamental rights as enshrined in the constitution. It posits that it is only through philosophy of Essencism that Nigeria can achieve holistic development.
\end{abstract}

\section{Introduction}

Religion could serve as an instrument of social harmony, and paradoxically, it could also serve as a motivation for violence hence, it has been viewed by scholars as a "double-edged sword" (Maregere 2011:17-23; Obasi 2009). Religious bigots right from the ancient epoch attempted to legitimize violence in the name of God. It is on the basis of this that present acts of extreme violence such as terrorist attacks as typified by Boko Haram in Nigeria are usually justified as "holy wars". In the last two decades, Nigeria had experienced events of tensions violence and killing between Christians and Muslims. These violent conflicts are not unconnected with the complex nature of interreligious and intercultural relationship that exists in the country, which have been that of religious fundamentalism and riots. The major reason for the violent conflict is largely due for either lack of understanding and misinterpretation of the various religious faiths. Added to this is the fact that the dominant model of religious learning ordered by major Nigerian regions has been faiths oriented and anchored on religious indoctrination and dogma. 
It is discoverable from this that education was a means of getting people to embrace Christianity or Islam instead of making it a process or formation for religious tolerance and dialogue. As a result of this, most children and youths are educated within this framework and as such are inclined to blind faith. Religious intolerance it could be argued is the outcome of the way that religious education is taught. This approach and indoctrination make it possible for people especially children to grow up being very intolerant, exclusive and with lack of openness to dialogue. The February, 2003 clash between Christian and Muslim students in some secondary schools in Oyo state over the wearing of the Islamic veil provide concrete evidence for this assertion. This has made it possible for Christianity and Islam to maintain their dominant influence on both the society and schools, and allowing no room for dialogue, respects for religious diversity, secularity status of the country as constitutionally provided, interreligious learning and co-existence.

Indeed, the challenges vary from the understanding in matters of faith and beliefs between members of the different religions in Nigeria, responses to pluralism, multicultural and multi-religious prospects and perspectives. The paper will examine the role of education in religious intolerance; evaluate the psychology of fundamentalism and its impact on religious intolerance. Also, the paper maintains that a sound philosophy of education in the mould of Essencism can help in curbing religious intolerance in Nigeria. In doing this, it will take into account the cognizance of the historical, cultural, sociological, psychological and ideological factors that may have contributed to religious intolerance in Nigeria.

\section{Religion in Nigeria}

There are several religions in Nigeria and this assist in the accentuation of regional and ethnic distinctions. As at 1990, all religions represented in Nigeria, were actually practiced in major cities (Wikipedia). The northern part of the country is dominated by Islam and there are some followers in the south west that constitute the Yoruba. Also, in the Yoruba axis there exist Protestantism and local syncretic Christianity. Among the Igbos of the South East and other closely related areas are dominated by Catholicism. Both Catholicism and Protestantism dominate the Ibibios, Annangs, and the Efiks of south-south Nigeria.

The 1963 census according to Wikipedia, showed that 47 percent of Nigerians were Muslim, 35 percent Christian and 18 percent belong to other local indigenous congregations. However, a 2003 report portrayed $50,4 \%$ of Nigerian as Muslims, $48,2 \%$ as Christian, while $1,4 \%$ are members of other religions. Among the Christians, we have catholic as $27,8 \%$, protestant $31,5 \%$, while other recent statistics give up to $55 \%$ of the Nigerian population to Muslim while Christians are $40 \%$.

This statistics cannot be relied upon wholly herefor the reason being that the Nigerian population has been manipulated for political, economic and other reason. Also, the Purdah system cannot help to provide an accurate census of the Moslem population in Nigeria.

In relation to the major ethnic groups and religious affiliations, the Hausas' in the North is $95 \%$ Muslim and $5 \%$ Christianity, the Yoruba tribe in the west have $60 \%$ Christians, 30\% Muslims and $10 \%$ belonging to other African religions. The Igbos in the East and the Ijaw in the south are $98 \%$ Christians (Catholics), while $2 \%$ practice other African religions. The middle belt of Nigeria is the largest minority group and they are Christians mostly with traditional religions and very few Muslim converts.

Basically, the major problems of Nigeria have been religion and ethnicity. These twin problems have been perennial and tend to defy all logic. This made it possible for religious intolerance to persist despite the pluralistic nature of the Nigerian state. Historically, the western experience is to move from the exclusivity of "eiuscuiusreligio" and try to create a secular state where politics and religion are kept apart. Nigeria typified an example of two major religious communities inhabiting two different religions. The goal of this is to secure each community the freedom to practice their religion and educate their young ones in the practice of such religion. This can be seen in the Nigerian constitution where it is expressed that the state "shall not adopt any religion as state religion" and that "every person shall be entitled to freedom of thought, conscience and religion, including freedom to change his religion, or belief, and freedom... to manifest and propagate his religion or belief in worship". This clearly shows that the balance of power between Muslims and Christians in Nigeria is such that it is difficult if not impossible to realize the dream of becoming dominant. The option here is the cultivation of tolerance and cooperation, which is necessary to secure freedom of worship that will promote peaceful coexistence. However, in practice, this balance of power tends to provoke an intensification of confrontation, which 
has led to the religious conflicts, violence and now terrorism. This indeed is a serious challenge to the Nigerian state. The present situation is capable of derailing the democratic structure and it posed a mortal danger to the unity of the country. The solution to this danger lies in Education and a philosophy of education that will recover the very head, the heart and hand of the very people that champion this conflict and redirect them toward reinventing their understanding and conception of religion, while locating the role of man in natural design. This approach will move the diagnosis of religious conflicts in Nigeria from the underlying socio-political, economic and governance factors and focus to a more holistic and practical means of providing a lasting solution to this problem.

\section{Religious Intolerance and Education in Nigeria}

Several causes of religious violence has been identified in some literature such as (Agwu 2009; Gofwen 2004; Salawu 2010, Iwara 2006, Kwaja 2009; Omotosho 2003, Sanusi 2009). The causes in this literature anchored on socio-political, economic and governance factors that gestate not only religious conflicts, but also violent conflicts in Nigeria as a whole. However, Sampson (2012) showed that government neglect, oppression, domination, exploitation, victimization, discrimination, marginalization, nepotism and bigotry are equally factors that can trigger off religious violence. Kwaja (2009:107) also in his treatise identifies the fragile nature of state institutions in relation to their ability and capacity to manage effectively diversity, corruption, rising inequality between the rich and the poor, gross violation of human rights, environmental degradation, contestation over land, among others as the reasons for violent conflicts in Nigeria. Indeed, several others reasons such as disparaging publications by both Christian and Muslim elites (Omotosho 2003), wrong perception of other people's religion or faith, wrong religious orientation, the low literacy level of religious adherents, selfishness on the part of religious personalities, pervasive poverty, government involvement in religious matters (Acgumike 2008:287) as factor responsible for interreligious conflicts in Nigeria.

A cursory look at all these factors reveals religious intolerance, fundamentalism and extremism. Indeed, this tripod is what carried the pot of religious conflicts in Nigeria. This tripod is however fuelled by lack of education that is on a sound philosophic foundation. This assertion tallies with the view of (Achunik, 2008), when he opines that low illiteracy level of religious adherents accounts for religious violence in Nigeria. Lack of proper education is the major reason for religious conflicts and violence in Nigeria. This is because proper education will equip religious adherents with better understanding of the dynamics of religion. Education helps to liberate the minds of religious adherents of all dogmas that tend to generate and create intolerance, fundamentalism and extremism. It places the adherents in a position to question certain religious views and dogmas that will be against the views of others. For instance, as a Christian, I am not convinced that it is only Christians that will make heaven. I am not also in agreement with the notion of "hell" as preached by Christianity. There are several reasons that informed this position and no preacher or gospel has been able to change it. This conviction or knowledge is not a product of dogma but rational deduction from Biblical, religious and philosophical views. It is a product of deep reflection nourished by intellectual fruits that emphasis that the medieval humanism and the renaissance view of man derived more from the Bible than from Greek philosophy, and that the Biblical view of man is not only compatible with freedom but has tended to be most effective guarantee of freedom in human society.

Education could to a great extent, aid Christians and even Moslem to compromise or give up some religious or doctrinal rights for the sake of social change, but the question is; how liberal or dogmatic could they be? For Christianity, the scriptures as can be seen in Roman 13:1-2, where Paul said:

Let every soul be subjects unto the higher powers. For there is no power but of God: the powers that be are ordained of God. Whosoever therefore resisteth the power resisteth the ordinance of God; and they that resist receive to themselves damnation.

Also, 1 Peter 2:13-14, Peter urged Christians to "Be subject to every kind of human order, whether it be to the King as the foremost, or governors as sent by him, as a vengeance on the wicked and a reward to the just". Here, liberal leaning towards authority in the Christendom will therefore make it possible for a Christian to respect the privacy of others. This is due to the realization of the fact that these aspects of other people's lives do not in any way fall under his jurisdiction. This belief nourished with education will make it impossible for a 
Christian to attempt to take over power of the state to sanction deviant behaviour, or would a Christian attempt to abate certain conduct that offends Christian doctrine. This is clearly within the regulatory purview of temporalauthority. This virtue of compliance to temporal authority makes it possible for Christianity to endorse and comply with economic, political and social order as sanctioned by temporal authority as far as these do not interfere with its worship.

Islam, on the other hand is different. It is not just a religion but also a way of life that encompasses the whole gamut of economic, judicial, political and cultural lives of its Umma (faithful or adherent), and as such it is viewed as "total submission to the will of Allah (God) as revealed through the prophetic message of Muhammed" (Danjibo). The totality of Islamic regulation of the lives of Muslims is graphically captured by Olayiwola (1988:227), when he writes:-

Islam does not admit a narrow view of religions by restricting it within the limits of worship, specific rituals and spiritual beliefs. In its precise meaning, Islam is not only a religion; it is also a way of lifer that regulates all the aspects of life on the scale of the individual and the nation. Islam is a social order, philosophy of life, a system of economic rules and government. Islam clearly establishes man's duties and rights in all relationship- a clear system of worship, civil rights, laws of marriage and divorce, inheritance, code of behaviour, laws of economy, laws of governance, laws of war and peace, of buying and selling and laws of relations and co-existence with one another, parents, children, relatives neighbours, guests, Muslims, nonMuslims and brethren.

This explanation tilts Islam towards intolerance, fundamentalism and extremism. It paints a picture of rigidity of Islam as a comprehensive tool for the regulation of the entire lifestyle of its faithful, where there exists no room for any separation between spiritual and temporal affairs especially for those that chose to be pious Muslims. This highlights absolution in the characterization of Islam as it is held by adherents of the Wahhabi Islam, who see jihad as a portent tool for the purging of Islam of modernization since it is seen as adulteration of orthodox principles. This offer succinct explanation to the predominance of religious violence in the Muslim dominated northern Nigeria where liberal attitude to Islamic orthodox or Wahhabism has given birth to Boko Haram and terrorism. Boko Haram is a product of the rigidity and inflexibility of Islamic fundamentalism of the Wahhabi extraction as they continue to react violently to any act or omission viewed as a violation of Sharia or Islamic tenets. This attitude ignores the fact that other religious sects have a corresponding legal right to the same act(s). So, the fundamentalists' effort to maintain a strict and pure Islamic state in a secular country is overtly and covertly a violation of the rights of other people and as such is ignition to religious violence (Achunike 2008:288)

The several religious disturbances ranging from the 1980 Maitatsine and the presentBoko Haram sectarian violence are all products of dogmatic adherence to Sharia jurisprudence that inspires Islamic Jihad and Obliteration of Western civilization (Ekanem 2011, Onuoha 2012). Also, the 1991 religious crisis that engulfed TafawaBalawa in Bauchi state was ignited by Muslims dreams to maintain religious purity in multi-cultural and multi-religious environment.

It is clear from the above analysis that dogmatism is one basic element of religious violence. Dogmatism as a product of indoctrination can be cured through education that seeks to liberate the minds and remove all forms of mental cobwebs gathered through cultural and religious activities and beliefs. Through education the perception of religious adherents could be altered positively. This can be seen in the Platonic "Allegory of the Cave" where education is portrayed as a light that liberate men from the chain of dogmas.

A deep reflection on the history of the northern part of Nigeria reveals very high level of illiteracy. This illiteracy of the majority of the northern masses exposed them to the manipulation of the few elites that employed religion and ethnicity as a tool for socio-political, economic and governance advantage. The northern masses have been deprived of education by the ruling elites.

This deprivation brought about government neglect, oppression, domination, exploitation, marginalization, nepotism and bigotry, poverty, inequality, gross violation of human rights, environmental degradation and subjugation. This is coupled with selfishness of the elites, corruption and weak institutions that are incapable of managing diversity and pluralism in the country.

All these are issues created due to lack of education especially in the northern state of Nigeria. This lack of education in northern Nigeria dates back to era of colonialism. This can be seen in the analysis of Lemu (2012) 
when he explained that the pattern of education in the south and the north has been different. In the south, Christian missionaries established schools freely but this was not the case in the north. This created educational disparities between the south and north. This disparity in a way has entrenched marginalization in terms of national development in the country.

However, the few northern elites capitalized on the seemingly high illiteracy rate in the north to subject the masses to adverse poverty and subjugation. This lack of education in the north left the masses with nothing to occupy their minds. The options left for the teeming masses are to recourse to religion for scour and as Karl Marx puts it, religion becomes an "opium of the poor (masses)". With the exclusivity nature of Islamic religion and its indoctrination and comprehensiveness as both a religion and way of life, this become a basic political and ethnic tool in the hand of the elitist cabal who inspire and indoctrinate them to take to violence as a means to combat un-Islamic activities.

From our analysis, it is evident that with education the human mind could be more liberally and positively engaged. Also, with education the level of rationality and analytic skill of the human person could be enhanced and this could have the potential to drastically reduce the high incidence of violence inspired by religion. This assertion is anchored on the fact that education sharpens the human intellect and equips man with the inquisitiveness that enables man to raise certain fundamental question. With education, I am sure most people with moderate and control their instinct for violence due to religion. For instance, it will take only an educated mind to raise the question of God existence. We are not to accept everything that religion preaches or propagates, and to be able tofree ourselves from religious indoctrination we need education as a veritable tool towards achieving this goal.

It is only an effectively manipulated mind through indoctrination that can decide to fight for God or gods. If God or $\operatorname{god}(\mathrm{s})$ is or are what $\mathrm{He}(\mathrm{he})$ is or are projected to be, then no man have the power or might to fight for God or gods. Vengeance we are told, belongs to God or gods, so why should a rational being wants to fight for the "Almighty God" and "gods" that have the power to destroy both the "body and the soul".

The Boko Haram insurgency and other related religious crisis in Nigeria that emanate from the northern part of the country is a clear confirmation of lack of education properly so called. What have been taken as a philosophy of education in the country are policy statements and objectives of education. Also, in the entire northern region there exits no department of philosophy in all the Universities established by the federal and states governments, except the recent ones by University of Abuja(the department lack the requisite man power for a fruitful academic activity to be regarded as philosophical) and Benue State University, which is ill equipped by qualified academic staff.

The lack of philosophy departments in the northern universities is not an oversight but a deliberate design to keep this portent and rigorous cognitive activity out of the northern region and therefore deprive the masses of the region the monumental benefits and illuminative potentials of such intellectual activity that philosophy can provide. It is the potency of philosophy to raise fundamental issues and question certain beliefsand thoughts. It is indeed the fear for the liberation of the masses from religious fundamentalism and bigotry that could be achieved through philosophy that made it difficult if not impossible for philosophy to penetrate the north. This singular act has left the north in the platonic cave without illumination. It becomes therefore an imperative for Nigeria to evolve a philosophy of education that will address this sordid and moral issue of religious intolerance.

\section{The Need for Essencism as a Philosophy of Education}

Essencismas a philosophy according to Ekanem (2005) is coined from the word "essence", which is what makes a thing what it is (Hornby 2004:392). Historically therefore, Essencism as a philosophy seeks to highlight the essence of man on planet earth. The reason for this unique philosophy, which is wholly Nigerian, is because most of the foreign philosophies tend to diminish the importance and value of the essence and life of man as the controller of the habitable earth. Also, some of these philosophies attempt to disconnect man from his creator and nature, while trying to dehumanize and alienate man. So, essencism is that philosophy that sees man as the centrality of all the happenings on earth. This position is anchored and traceable to the Biblical era, where man was given that divine authority to inherit the earth and dominate it. The book of Genesis made us to understand that God created man in his own image, to have both physical and spiritual dominion over all things. 
As the last thing that God created before his rest, man truly represents the divine authority of God. Man accordingly is God's ambassador and as an ambassador he is divinely immuned from harm or being harm by any thing on earth. Furthermore, the creation as we have it in the book of Genesis shows that man was put in the "Garden of Eden" to tend it. Also, it was man that provided names for virtually everything both in the garden and on earth. This is because, the Garden of Eden by design, is a microcosm of our earth that we live.

We can glean from this that man is imbued with divine intelligence and knowledge to fulfill God's purpose on earth. It follows then that the education of man must necessarily seek to establish this essence, that is, those important qualities that make man who he is by God. These qualities of man can be seen in the dual nature of man as both physical and spiritual being. This duality is what constitutes the essence of man. Hence, any philosophy or idea that diminishes or tends to de-emphasize that dualism must be rejected. Man indeed was created for a divine purpose. Man was created for the purpose of dominating his environment as established by God. So, man's stay at the Garden of Eden was to equip him with divine education that will aid him to cope and dominate his environment outside the garden.

This portrays that historically, man's education was divinely designed to reflect his techno-nature. This can be seen in man's divine ability to give names to all things created by God without duplication. From this, it can be said that the education of man is divinely inspired. Based on this inspirational dimension, education seeks to satisfy the spiritual essence of man while the applied science-technology actualized the physical manifestation of man's spiritual development.

Viewed from the essencist perspective, education of man is divinely ordained to satisfy the dual nature of man. So, any education that does not seek to achieve these two basic objectives is not a sound education. It is on the basis of this that we stand to condemn any education that only strives to justify the spiritual aspect of man while ignoring the physical aspect. This is where Boko Haram and other fundamentalist group lost the moral tonic and justification for their war against western education that strive to bring up a balanced man through a kind of education that cater for the spiritual and physical needs of man. Ekanem (2005:220), captures this aptly when he argues that

\begin{abstract}
...any educational philosophy that seeks to promote technological advancement must first and foremost, lay a spiritual foundation for its education. It is this spiritual development that can lead to inspirational advancement of knowledge, which practical applicability will lead effortlessly to technological development. This then satisfies the physical essence of man since it is through technological advancement that man is provided with his physical comfort. But for the physical comfort to be attained there must be a corresponding spiritual level of development. Also inclusive in this spiritual aspect of man's essence is the ethical value for all that is good. It provides man with a sound knowledge of what is good and bad.
\end{abstract}

The knowledge that essencism will provide will lay bare to all Nigerian citizens and make it possible as a socio-cultural practice that honesty pays and that intolerance of one another is a vice. It will also help to wipe off the culture and practice of killing in the name of religion. Essencism will bring to the fore the sanctity of human life. It will help change the culture and practice of looting the national treasury through public office. Also, it will instill in every Nigerian a nationalistic spirit of oneness thereby eradicating tribalism, religious bigotry, corruption and other socio-political vices that retard national development. The attainment of these sociocultural reforms through essencism is because the dual aspect of every citizen will be developed through this educational philosophy. This is because as a spirit being, man is directly linked with God from where the source of his intellectual inspiration is derived.

The spiritual development of man (Nigerians) through essencism will re-establish a direct link with God. And when God is involved in every affairs of man, we can be sure that harmony will be established and development is bound to occur with so much ease. This is because; Nigerians will have one source of intellectual inspiration, which is God. This will let Muslims, Christians, traditionalists, Eckists, humanists and others to see man as man and humanity will be better understood while our "Nigerianness" will emerge from this. This way, the act of violence against one another will be eliminated from our national life. This is because fighting against any Nigerian will be seen or interpreted as fighting against oneself.

Philosophy of essencism seeks to develop a complete human personality. This is because no aspect of the human nature is ignored. Man (Nigeria) is totally developed as a physical and spiritual being through essencism. It is when the human personality is completely developed that one can begin to talk of other aspects of 
development. This is because; the development of any nation is dependent upon the development of human person. Omoregbe (1990:147) supports this view when he asserts that:

The most important aspect of the development of any country is indisputably the development of human personality. It is, in other words, the moral development of the citizens that constitute the country. To be sure, there are other aspects of development, for a country is a living organism with many parts, each of which needs to be developed...

This is a sound logic and a fact that cannot be faulted or disputed. The development of a country is entirely dependent on the development of the people that make up such a country. This is in conformity with the platonic notion that the state is "man-writ-large". Also, if any part of the human person remains undeveloped, there is bound to be problem with the developmental process of such a country.

Nigeria as a nation needs essencism as a philosophy since it is the combination of the physical and spiritual dimensions of man into a whole that will create a unique system, character and culture for the Nigerian state through education. This combination will help the country to check and eradicate those vices that tend to retard and inhibit the development of the country.

\section{Recommendations}

Essencism as a philosophy of education in Nigeria can help promote development in the country and assist in curbing the menace of religious intolerance if the following are systematically carried out by the government.

- Promotion of religious understanding among youth aged 8 to 18 to form the backbone of diverse communities across Nigeria. This will serve as critical social cohesion.

- Enacting of legislation that will ban the receiving of religious education from teachers of their own faith. This is because the idea of teachers of the same faith teaching the students enrolled in pubic schools limit students opportunities to learn about other religion other than their own. There is the need to expose studentsto discussions on religious differences and pluralism.

- Promotion of local and national debate on religious tolerance.

- Production and distribution of comic books about religious differences and tolerance to students in public schools and the almajiris.

- Ensuring that religious education teachers are well grounded and trained in essencism as a philosophy of education.

- Building capacity for the rural poor/nomads.

- Promotion and fostering awareness about critical thinking, skills related to radicalization, religious freedom and tolerance.

- The institution of programming in public schools that will aids in the prevention of radicalization and promotes religious freedom and tolerance.

- The civil society and education should promote the idea of human rights as a tool for the promotion of religious intolerance.

- Victims of religious intolerance should be encouraged to seek redress in the court of law for the abuse of the fundamental rights.

- Promotion of tolerance and religious dialogue through education and the involvement of civil society in the process.

- The consistent promotion secularity status of Nigeria to education and public awareness.

- Government at all levels should not be involved in the funding of any religious activities.

- Liberalism should be promoted in all sphere of our national life.

\section{Conclusion}

Our analysis show that religious intolerance is a serious national issue in Nigeria, and it pose a mortal danger to the unity, stability and development of the country. Religious intolerance and it potentials to conflict and 
violence makes it a sensitive issue of national discourse. However, to tackle the challenges presented by this, the paper posits that education as a basic tool and vehicle of liberation can effectively be employed in solving this growing national monster. To achieve this, there is the need to lay a sound foundation for our education through a philosophy, which in this case is Essencism. This philosophy will also enhance Nigeria's level of sensibility in physical, spiritual and practical creativity.

This will provide Nigeria a practical and workable philosophy of education, which processes will help cultivate in Nigerians a high level of "physic-spiritual sensibility". For as Nwoko puts it "...A philosophy of education determines basically the direction of the creative and productive development of a people" (75).

Again, O'connor believes in the soundness of this logic when he asserts that "The educational system of any society is a more or less elaborate social mechanism designed to bring about in the persons submitted to it certain skills and attitudes that are judged to be useful and desirable in the society..."(74). From this, we can see that no meaningful development can take place without peace, a sound and appropriate philosophy of education because it is from here that we derive the aims of knowledge, skills and attitude.

With Essencism as a philosophy of education, a new culture and character that reflects the totality of man as a person that lives in peace with one another while preserving life, and Nigerians will not be cajoled into pursuing a religion and activities that will be detrimental to the sanctify of human life and destructive of natural law or principles. This will help redirect all Nigerians and provides the focus and knowledge that humanity is one and all Nigerians derive their existence from this.

Again, this will help to establish epistemological relationship between education, culture, religion, politics, peace and development. It will at the same time, place the services of education and religion to all the citizenry. Of greater importance of this philosophy is the fact that it purges the populace from hatred and intolerance but rather will provide a combination of critical reflection and judgment of religious activities. This will greatly checkmate the awesome impact of religious intolerance in our culture, and create the necessary atmosphere for peace and sustainable development in Nigeria.

\section{References}

Achunike, H.C. Religious practices in Nigeria as a source of conflict, Journal of Liberal studies, 2008, 12 (1 \& 2),pp 286-295

Adebayo, R.I. "Ethno-religious Crises and the Challenges of Sustainable Development in Nigeria." Journal of Sustainable Development in Africa 2010, 12 (4), Pp 213-225.

Agwu, C.T. "Religious Conflicts in Kano and Kaduna". In Ikejiani-Clarke, M.ed. Peace Studies and Conflict Resolution inNigeria: A reader, Ibadan: Spectrum books 2009, Pp. 518 - 531.

Bologun, K.A. "Religious intolerance as a source of National disintegration; In Mala, S. B. ed. Religion and NationalUnity, Ibadan University Press, 1988.

Ekanem S.A. "A Philosophy of Education for Technological Development in Nigeria" A Doctor of Philosophy (Ph.D) Dissertation, University of Calabar, 2005.

Gofwen, R.I. Religious Conflicts in Northern Nigeria and Nation Building: The Throes of Two Decades 1980- 2000, Kaduna: Human Rights Monitor 2004.

Iwara, U.E. "Religious Violence in Nigeria: Causes and Consequences" SOPHIA: An African Journal of philosophy, 2006, 8 (2), Pp. 153-157.

Kwaja, C.M.A. Strategies for Rebuilding State Capacity to Manage Ethnic and Religious Conflict in Nigeria".The Journal of Pan Africa Studies, 2009, 3 (3), Pp 105 -115.

Maregere, T.P. "Religious: A Source of Conflict and a Recourse for Peace. Conflict Trends Issue 1, 2011, Pp 17-23.

Obasi, C.O. "The role of religion on Issues of conflict and peace". In conflict Resolution in Nigeria: A reader. Ibadan: Spectrum Books 2009.

O'Connor, D.J. An Introduction to Philosophy of Education: London: Routledge \& Kegan Paul, 1980.

Olayiwola, A. "Nationalism and Nation Building in Islam" In Momoh, C.S. ed. Religion and Nation Building: Nigerian Studies in Religious Tolerance Vol. 1, Lagos, centre for Black and African Arts and civilization, and National Association for religions Tolerance, 1988.

Omoregbe, J.I. Knowing Philosophy Lagos: Joja Educational Research and Publishing, 1990.

Onuoha, F.C. The Audacity of the Boko Haram: Background, Analysis and Emerging Trend, 2012, Security Journal, 25, Pp. $134-151$.

Salawu, B. "Ethno-religious conflicts in Nigeria: Causal Analysis andProposal for New Management Strategies". European Journal of Social Sciences, 2010, 13 (3), Pp. 345-353. 